\title{
Therapeutic effects of dimethyldiguanide combined with clomifene citrate in the treatment of polycystic ovary syndrome
}

\author{
(iD) Jingjing Jiang ${ }^{1}$ \\ iD Shanshan Gao' \\ (iD) Yang Zhang ${ }^{1}$
}

1. Center for Reproductive Medicine, Shandong University, NO.324 Jingwu Road, Jinan City, Shandong Province, 250001, China.

http://dx.doi.org/10.1590/1806-9282.65.9.1144

\begin{abstract}
SUMMARY
OBJECTIVE: In view of the high incidence of polycystic ovary syndrome (PCOS) and the unsatisfactory therapeutic effects of dimethyldiguanide or clomifene citrate alone, our study aimed to investigate the therapeutic effects of dimethyldiguanide combined with clomifene citrate in the treatment of PCOS.

METHODS: A total of 79 patients with POCS and 35 healthy females were included, and endometrial biopsies were obtained. The sterol regulatory element-binding protein-1 (SREBP1) expression in endometrial tissues was detected by qRT-PCR. POC patients were randomly divided into group $A(n=40)$ and group $B(n=39)$. Patients in group $A$ were treated with dimethyldiguanide combined with clomifene citrate, while patients in group $B$ were treated with clomifene citrate alone. The number of mature follicles and cervical mucus score, follicular development rate and single follicle ovulation rate, cycle pregnancy rate, early miscarriage rate, ovulation rate, endometrial thickness, positive rate of three lines sign, follicle stimulating hormone level and luteinizing hormone level were compared between the two groups.

RESULTS: The expression level of SREBP1 was higher in PCOS patients than that in the healthy control. SREBP1 expression was inhibited after treatment, while the inhibitory effects of combined treatment were stronger than those of clomifene citrate alone. Compared with clomifene citrate alone, the combined treatment improved cervical mucus score, follicle development rate, single follicle ovulation rate, endometrial thickness, positive rate of three lines sign, and follicle-stimulating hormone level.
\end{abstract}

CONCLUSION: The therapeutic effect of combined treatment is better than clomifene citrate alone in the treatment of PCOS.

KEYWORDS: Polycystic ovary syndrome. Clomiphene. Metformin. Sterol Regulatory Element Binding Protein 1.

\section{INTRODUCTION}

Polycystic ovary syndrome, or PCOS, is one of the most common endocrine disorders, affecting more than $7 \%$ of females during their reproductive age ${ }^{1}$. At present, PCOS is mostly defined as hyperandrogenism-induced chronic anovulation in females who are not suffering from pituitary gland or adrenal diseases $^{2}$. PCOS is not only closely correlated with the occurrence of anovulatory infertility but is also one of the major risk factors for the development of various types of ovary cancer ${ }^{3}$. Although abnormal gonadotropin secretion has been proved to closely correlate with hyperandrogenism and anovulation, the pathogenesis of PCOS still hasn't been fully elucidated ${ }^{4}$. At hormone level, the excessive production of luteinizing hormone during PCOS can increase testosterone level, leading to the arrest of ovarian folliculogenesis ${ }^{5}$. Although various types of drugs have been developed to treat PCOS, treatment outcomes are usually unsatisfactory. 
Therefore, the development of an effective and safe treatment drug for PCOS is always in high demand.

Previous studies have shown that dimethyldiguanide $^{6}$ and clomiphene citrate ${ }^{7}$ have protective effects for patients with PCOS, and both of them can be used to induce ovulation and pregnancy. However, their efficacies should be further improved to meet the treatment requirement. In this study, dimethyldiguanide were combined with clomiphene citrate to treat patients with PCOS. We found that the therapeutic effects of combined treatment are stronger than those of clomiphene citrate alone.

\section{METHODS}

\section{Patients}

A total of 79 patients with polycystic ovary syndrome (PCOS) in reproductive age were selected from a reproductive hospital affiliated to Shandong University from august $2012 \sim$ august 2014 . The age ranged from 24 to 39 years, with a mean age of $27.11 \pm 4.28$ years. All those patients underwent an endometrial biopsy to detect potential ovarian lesions. Inclusion criteria: (1) patients who did not take contraception or were pregnant during the past year; (2) patients who met the diagnostic criteria of $\mathrm{PCOS}^{8}$; (3) patients who did not receive reproductive hormones or ovulation induction treatment during the past 3 months; (4) lipiodolized angiography showed that at least one side of the uterine tube was unobstructed; (5) patients who signed informed consent; (6) male partner had a sperm test $a+b$ total $>107$. Exclusion criteria: (1) patients with other disorders of the ovary; (2) patients with a history of ovarian surgery; (3) patients with high levels of androgen caused by other diseases. At the same time, 35 healthy females were selected to serve as a control group. Inclusion criteria of the control group: females with normal physiological conditions; 2) females who matched the age distribution of the patient group. Exclusion criteria: 1) females who were not willing to participate; 2) females who failed to cooperate with researchers. Healthy women had difficulties in getting pregnant, while endometrial biopsies showed no existence of lesions. The age of those healthy females ranged from 23 to 40 years, with a mean age of $26.99 \pm$ 3.57 years. No significant differences in age, BMI, and other basic information were found between the two groups. This study has been approved by the Ethics Committee of Shandong University. All participants signed informed consent.

\section{Grouping and treatment}

Patients were randomly divided into group $A(n=40)$ and group $B(n=39)$. Patients in group A were treated with dimethyldiguanide (long-acting $2.5 \mathrm{~g}$ metformin, once per day, Bristol-Myers Squibb) combined with clomifene citrate (50 mg per time, once per day, hengshan pharm) for 5 days (day 3 to day 7 of the menstrual cycle). Patients in group B were only treated with clomifene citrate during the same period. From the 8th day of the menstrual cycle, a daily vaginal ultrasound examination was performed to monitor follicular development. Human chorionic gonadotropin (hCG) was injected via intramuscular injection in patients of group A and B when the mean diameter of the largest follicles monitored was $>=20 \mathrm{~mm}$. No significant differences in general information were found between group A and B (Table 1).

\section{Observation indices}

Vaginal ultrasound examination was performed by the same professional physician before and after the treatment to calculate the positive rate of three lines sign, measure the endometrial thickness, and count bilateral ovarian follicles (measured 3 times for the average). Based on the endometrial thickness and ovarian follicle number, the cycle pregnancy rate (one cycle), early abortion rate, periodic ovulation rate, single follicle ovulation rate, follicular growth rate, and other indicators were calculated. The number and size of follicles were monitored since the 10th day of the menstrual cycle by vaginal ultrasound. Cervical mucus examination and scoring were performed from the 14th day of the menstrual cycle, and the formation of typical ovate crystals and oval body indicated ovulation. Levels of follicle-stimulating hormone and luteinizing hormone were measured 3 days after treatment.

\section{Real-time quantitative PCR}

Total RNA was extracted from endometrial tissues using Trizol reagent (Invitrogen, USA). RNA samples were tested by NanoDrop ${ }^{\mathrm{Tm}} 2000$ Spectrophotometers (Thermo Fisher Scientific, USA), and the ones with a A260/A280 ratio between 1.8 and 2.0 were used to synthesize cDNA through reverse transcription. The following primers were used in PCR reactions: 5'-GCGGAGCCATGGATTGCAC11-3' (forward) and 5'-CTCTTCCTTGATACCAGGCCC-3' (reverse) for SREBP1; GACCTCTATGCCAACACAGT (forward) and AGTACTTGCGCTCAGGAGGA (reverse) for $\beta$-actin. PCR reaction conditions were: $95{ }^{\circ} \mathrm{C}$ for $30 \mathrm{~s}$, followed 
by 40 cycles of $95{ }^{\circ} \mathrm{C}$ for $12 \mathrm{~s}$ and $60{ }^{\circ} \mathrm{C}$ for $32 \mathrm{~s}$. Data were analyzed using the $2-\Delta \Delta \mathrm{CT}$ method. The relative expression level of SREBP1 was normalized to endogenous control $\beta$-actin.

\section{Statistical analysis}

SPSS19.0 (SPSS Inc., USA) was used to perform the analysis. Data followed a normal distribution. Measurement data were recorded by ( $x \pm s)$, and comparisons between two groups were performed by t-test. Count data were processed by the Chi-square test. P-value $<0.05$ was considered to be statistically significant.

\section{RESULTS}

Sterol regulatory element-binding protein-1 (SREBP1) expression was upregulated in endometrial tissues of patients with PCOS

Expression of SREBP1 in endometrial tissues of both PCOS patients and normal healthy females was detected and compared. As shown in Fig. 1, the

TABLE 1A. COMPARISON OF GENERAL INFORMATION BETWEEN GROUP A AND B

\begin{tabular}{l|l|l|l|l} 
Groups & Cases & BMI & Age & Course of disease (years) \\
\hline $\mathrm{A}$ & 40 & $21.61 \pm 3.82$ & $27.46 \pm 3.48$ & $3.7 \pm 1.3$ \\
\hline $\mathrm{B}$ & 39 & $20.88 \pm 3.44$ & $26.87 \pm 4.01$ & $3.3 \pm 1.5$ \\
\hline $\mathrm{c} 2$ or $\mathrm{F}$ & \multirow{2}{*nnnn}{$\mathrm{P}$} & 0.48 & 1.07 & 1.04 \\
\hline & & 0.89 & 0.36 & 0.35 \\
\hline
\end{tabular}

TABLE 1B. COMPARISON OF THE NUMBER OF MATURE FOLLICLES AND CERVICAL MUCUS SCORE BETWEEN THE TWO PATIENT GROUPS $(X \pm S)$

\begin{tabular}{l|l|l|l} 
Groups & Cases & \multicolumn{1}{l}{ Number of mature follicles } & Cervical mucus score \\
\hline A & 40 & $3.17 \pm 0.68^{*}$ & $11.61 \pm 2.43^{*}$ \\
\hline B & 39 & $2.32 \pm 0.41$ & $7.19 \pm 3.51$ \\
\hline
\end{tabular}

Notes:"compared with group $B, p<0.05$

TABLE 1C. COMPARISON OF OVULATION INDUCTION EFFECT BETWEEN THE TWO PATIENT GROUPS [ N(\%)]

\begin{tabular}{l|l|l|l|l|l|l} 
Groups & \multicolumn{2}{c}{ Cases } & \multicolumn{2}{c}{$\begin{array}{l}\text { Cycle preg- } \\
\text { nancy rate }\end{array}$} & \multicolumn{2}{l}{$\begin{array}{l}\text { Early miscar- } \\
\text { riage rate }\end{array}$} \\
\hline A & 40 & $9(23.07 \%)$ & $3(7.69 \%)$ & $16(41.03 \%)$ & $17(43.59 \%)$ & $14(35.90 \%)$ \\
\hline B & 39 & $9(22.5 \%)$ & $7(17.5 \%)$ & $17(42.5 \%)$ & $11(27.5 \%)$ & $7(17.5 \%)$ \\
\hline
\end{tabular}

Notes:"compared with group B, $p<0.05$

TABLE 1D. COMPARISON OF ENDOMETRIAL THICKNESS AND POSITIVE RATE OF THREE LINES SIGN BETWEEN THE TWO PATIENT GROUPS

\begin{tabular}{l|l|l|l}
\multicolumn{1}{l}{ Groups } & Group & \multicolumn{1}{l}{ Endometrial thickness $<7 \mathrm{~mm}$} & \multicolumn{1}{l}{ Positive rate of three lines sign } \\
\hline A & 40 & $7(17.95 \%)^{*}$ & $12(30.77 \%)$ \\
\hline B & 39 & $19(47.5 \%)$ & $7(17.5 \%)$ \\
\hline \multicolumn{2}{l}{ Notes: compared with group B, $p<0.05$}
\end{tabular}

TABLE 1E. COMPARISON OF HORMONE LEVELS BETWEEN TWO PATIENT GROUPS $(X \pm S)$

\begin{tabular}{l|l|l|l} 
Groups & Cases & \multicolumn{1}{l}{ Follicle-stimulating hormone (IU/L) } & \multicolumn{2}{l}{ Luteinizing hormone (IU/L) } \\
\hline A & 40 & $8.19 \pm 1.20^{*}$ & $4.55 \pm 1.24 \#$ \\
\hline B & 39 & $4.03 \pm 1.51$ & $5.01 \pm 1.77 \#$ \\
\hline Control & 35 & $9.17 \pm 1.33$ & $2.87 \pm 0.31$ \\
\hline
\end{tabular}

Notes: ${ }^{*}$ compared with group $B, p<0.05$; \# compared with the control group, $p<0.05$ 
expression level of SREBP1 was significantly higher in endometrial tissues of PCOS patients than that in normal healthy females $(\mathrm{p}<0.05)$.

\section{Expression of SREBP1 in different groups be-} fore and after the treatment

Before treatment, no significant differences in the expression level of SREBP1 mRNA were found between group A and B (Fig. 2a). Compared with the pre-treatment levels, the expression level of SREBP1 mRNA was significantly reduced in both group A ( $p<0.05$, Fig. $2 b)$ and group B ( $p<0.05$, Fig. $2 c)$. After the treatment, no significant differences in the expression level of SREBP1 mRNA were found between group A and the control group (Fig. 2d), while the expression level of SREBP1 mRNA was significantly higher in group B than that in group A or the control group. Those data indicate that both combined treatment and clomifene citrate alone can inhibit the expression of SREBP1 mRNA in endometrial tissues, while the inhibitory effect of the combined treatment was stronger than that of clomifene citrate alone.

Comparison of mature follicles number and cervical mucus score between two patient groups

After the treatment, the number of mature follicles in group A was higher than that in group B $(p<0.05)$. In addition, cervical mucus score was also higher in group A than that in group B $(p<0.05)$.

\section{Comparison of ovulation induction effect be-} tween two patient groups

After the treatment, the follicular development rate was significantly higher in group A than that in group B $(p<0.05)$. In addition, the single follicle ovulation rate was also slightly higher in group $\mathrm{A}$ than that in group B at $48 \mathrm{~h}$ to $60 \mathrm{~h}$ after injection of hCG. However, no significant differences in cycle pregnancy rate, early miscarriage rate, and ovulation rate were found between the two groups.

Comparison of endometrial thickness and positive rate of three lines sign between two patient groups

After treatment, the number of PCOS patients with endometrial thickness $<7 \mathrm{~mm}$ in group A was significantly smaller than that in group $B(p<0.05)$. In addition, the positive rate of three lines sign was also slightly higher in group A than that in group B, but the difference was not statistically significant.

Comparison of hormone levels between the two patient groups and the control group

After treatment, the level of follicle-stimulating hormone in group A was significantly higher than that in group $B(p<0.05)$, and reached the level of the control group. However, no significant differences in the level of luteinizing hormone were found between two patient groups after the treatment; however, the luteinizing hormone level in group A and B was still significantly higher than in the control group.

\section{DISCUSSION}

The development of PCOS is a complex process with various internal and external factors involved. It has been well accepted that the abnormal production of sexual hormones is closely correlated with the occurrence, development, and progression of this disease. Hyperandrogenism in women with PCOS is characterized by an increased level of tosterone ${ }^{9}$. Besides that, increased luteinizing hormone/follicle-stimulating hormone ratio caused by reduced production of follicle-stimulating hormone and increased production of luteinizing hormone is also a common hormonal feature of PCOS ${ }^{9}$. Recent studies have also shown that excessive secretion during PCOS is responsible for the reduced secretion of follicle-stimulating hormone and the production of testosterone, as well as the increased luteinizing hormone/follicle-stimulating hormone ratio, which is a key factor for the arrest of ovarian folliculogenesis ${ }^{8,9}$. Dimethyldiguanide has been proved to regulate the abnormal secretion of follicle-stimulating hormone and luteinizing hormone in patients with $\mathrm{PCOS}^{6}$. Similar therapeutic effects of clomiphene citrate were also observed in the clinical treatment of PCOS $^{7}$. In our study, the level of follicle-stimulating hormone in patients with combined treatment was significantly higher than in patients who underwent the clomiphene citrate treatment alone and reached the level of the control group. However, no significant differences in the level of luteinizing hormone were found between the two patient groups after the treatment, but the luteinizing hormone level in the two patient groups was still significantly higher than that in control group. Those data suggest that, compared with the clomiphene citrate treatment alone, the combined treatment can significantly increase the 
FIGURE 1. EXPRESSION OF SREBP1 IN ENDOMETRIAL TISSUES OF BOTH PCOS PATIENTS AND NORMAL HEALTHY FEMALES

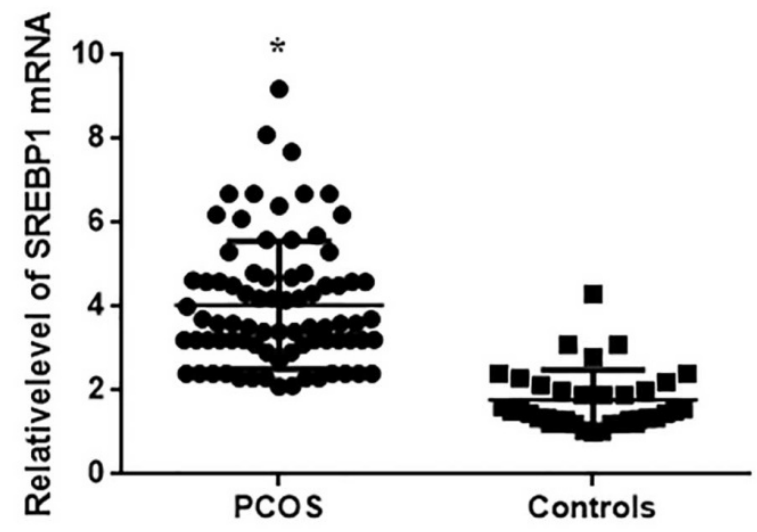

FIGURE 2. EXPRESSION OF SREBP1 IN DIFFERENT GROUPS BEFORE AND AFTER TREATMENT
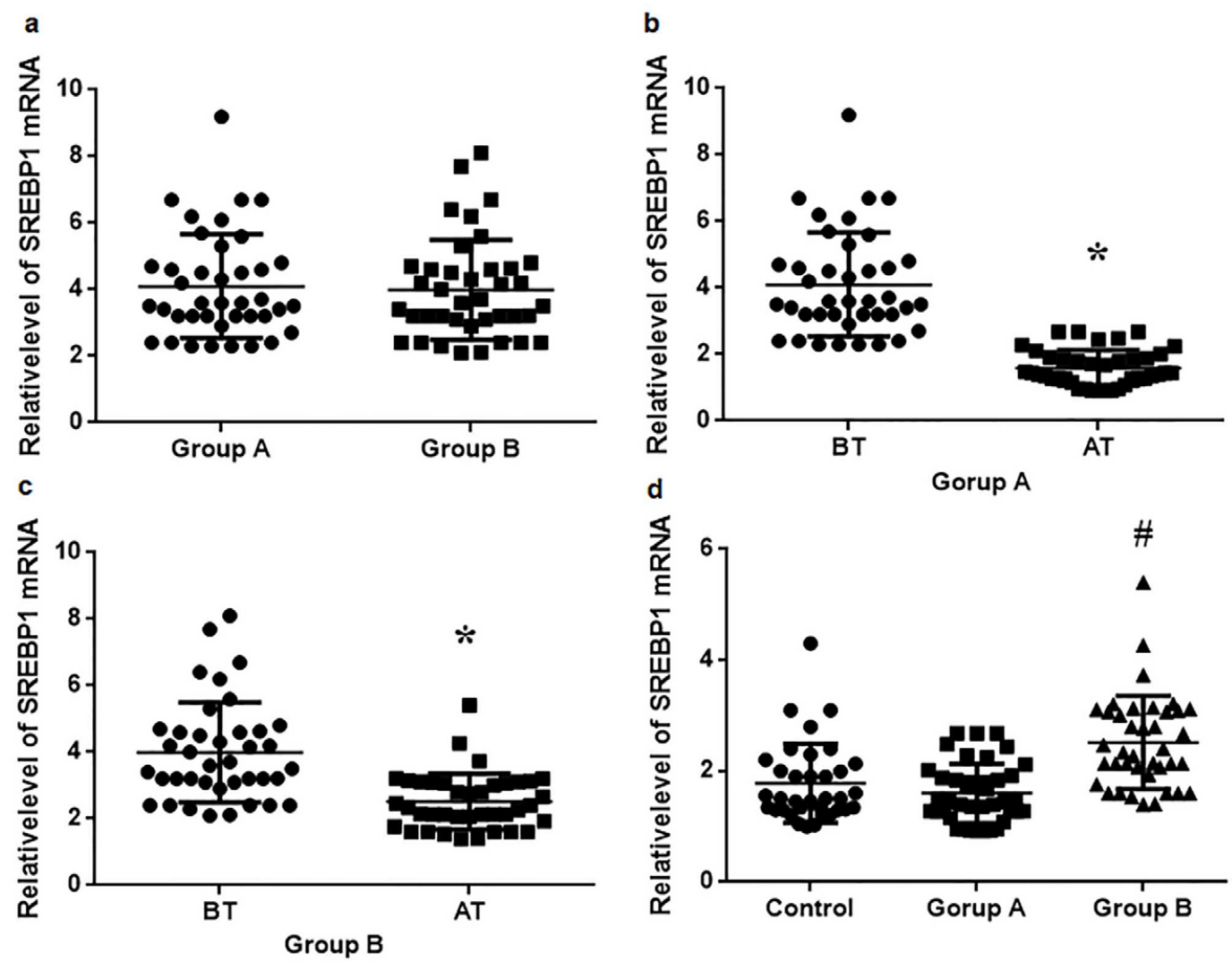

a Expression of SREBP1 in group A and B before treatment; $\mathbf{b}$ Expression of SREBP1 in group A before and after treatment; $\mathbf{c}$ Expression of SREBP1 in group $B$ before and after treatment; $\mathbf{d}$ Expression of SREBP1 in group A, group B, and control group after treatment.

Notes: * ${ }^{*}$ compared with the level before treatment, $p<0.05$; \#compared with the control group and group $A, p<0.05$ 
enhancing effects on the secretion of follicle-stimulating hormone, but had no significant impact on the inhibitory effects of the secretion of luteinizing hormone. Our data provided references for the combined use of clomiphene citrate and dimethyldiguanide in the treatment of PCOS. Clomiphene citrate and dimethyldiguanide may be combined with other drugs that can reduce luteinizing hormone to improve the treatment further.

Numerous studies have shown that both dimethyldiguanide and clomiphene citrate have protective effects for patients with PCOS, and treatment with dimethyldiguanide or clomiphene citrate alone can significantly induce ovulation and pregnancy. In this study, compared with the clomifene citrate treatment alone, dimethyldiguanide combined with clomifene citrate significantly improved cervical mucus score, follicle development rate, single follicle ovulation rate, endometrial thickness and positive rate of three lines sign. Those data suggest that the combined treatment is superior to the clomifene citrate treatment alone in various indices for the treatment of PCOS. However, compared with patients who were treated with clomifene citrate alone, no significant improvement in pregnancy rate, early miscarriage rate, and ovulation rate was observed in patients with the combined treatment. Therefore, ways to further improve those indices will be the focus of future work.

Genetic factors also play pivotal roles in the treatment of PCOS. SREBF1 is a transcription factor that binds to the promoter regions of a variety of genes to regulate their expressions. Abnormal expression of SREBF1 exists in various disease models, such as Parkinson's, non-alcoholic fatty liver disease, among others. Recent studies have shown that $54 \mathrm{G} / \mathrm{C}$ polymorphism of SREBF-1 gene is closely associated with the development of PCOS. In addition, abnormal upregulated SREBP1 is observed not only in endometrial cancer but also in PCOS. Consistent with previous studies, in this study, the expression level of SREBP1 was found to be significantly higher in the endometrial tissues of PCOS patients than that in normal healthy females, indicating the involvement of this gene in PCOS. Both combined treatment and clomifene citrate alone inhibited the expression of SREBP1 mRNA in endometrial tissues, while the inhibitory effect of combined treatment was stronger than that of clomifene citrate alone. Those data suggest that the combined treatment may inhibit the expression of SREBP1 to improve PCOS.

It has been reported that dimethyldiguanide can inhibit CYP-17 expression and reduce theca cell proliferation in androgenized rat models, thereby improving ovarian follicle dynamics ${ }^{10}$. Therefore, the improved therapeutic effects of the combined treatment are possibly mediated by the altered CYP-17 expression and theca cell proliferation. Our future studies will try to investigate this possibility. Our study provided a promising combined treatment for PCOS. However, it is worth noting that PCOS is a reproductive disorder as well as a complex metabolic disease; therefore, the treatment should be individualized. Some factors, such as patients' pregnancy plans and the risk of longterm complications should be considered before the selection of treatment strategies ${ }^{11}$. Therefore, more studies are still needed to explore the individualized treatment for PCOS further.

In is worth noting that our studies failed to investigate the gene polymorphism of SREBP1 in PCOS, so the opposite correlation cannot be excluded. Therefore, more studies are still needed.

\section{CONCLUSION}

In conclusion, the expression level of SREBP1 was higher in PCOS patients than that in the healthy control. SREBP1 expression was inhibited after treatment, while the inhibitory effects of combined treatment were stronger than those of clomifene citrate alone. Compared with clomifene citrate alone, the combined treatment improved the cervical mucus score, follicle development rate, single follicle ovulation rate, endometrial thickness, positive rate of three lines sign, and follicle-stimulating hormone level. Therefore, we conclude that the therapeutic effect of combined treatment is better than that of clomifene citrate alone in the treatment of PCOS. The small sample size limits our study. Further studies with bigger sample size are expected to confirm our conclusion. 


\section{RESUMO}

OBJETIVO: Tendo em vista a alta incidência de síndrome dos ovários policísticos (SOP) e os efeitos terapêuticos insatisfatórios da dimetildiguanida ou do citrato de clomifeno isoladamente, nosso estudo teve como objetivo investigar os efeitos terapêuticos da dimetildiguanida associada ao citrato de clomifeno no tratamento da SOP.

MÉTODOS: Um total de 79 pacientes com POCS e 35 mulheres saudáveis foram incluídos, e biópsias endometriais foram obtidas. A expressão da proteína de ligação do elemento regulador de esterol-1 (SREBP1) nos tecidos endometriais foi detectada por qRT-PCR. Pacientes POC foram divididos aleatoriamente em grupo $A(n=40)$ e grupo $B(n=39)$. Os pacientes do grupo $A$ foram tratados com dimetildiguanida combinada com citrato de clomifeno, enquanto os pacientes do grupo $B$ foram tratados apenas com citrato de clomifeno. O número de folículos maduros e muco cervical, taxa de desenvolvimento folicular e taxa de ovulação, taxa de gravidez, abortamento precoce, taxa de ovulação, espessura endometrial, taxa positiva de três linhas, nível de hormônio folículo estimulante e nivel de hormônio luteinizante foram comparados entre os dois grupos.

RESULTADOS: O nível de expressão do SREBP1 foi maior nos pacientes com SOP do que no controle normal. A expressão de SREBP1 foi inibida após o tratamento, enquanto os efeitos inibidores do tratamento combinado foram mais fortes do que os do citrato de clomifeno isoladamente. Comparado com o citrato de clomifeno sozinho, o tratamento combinado melhorou significativamente a pontuação do muco cervical, a taxa de desenvolvimento folicular, a taxa de ovulação do folículo único, a espessura endometrial, a taxa positiva de três linhas de sinal e o nível de hormônio folículo estimulante.

CONCLUSÃO: O efeito terapêutico do tratamento combinado é melhor do que o citrato de clomifeno isolado no tratamento da SOP.

PALAVRAS-CHAVE: Síndrome do ovário policístico. Clomifeno. Metformina. Proteína de ligação a elemento regulador de Esterol 1.

\section{REFERENCES}

1. Flannery CA, Rackow B, Cong X, Duran E, Selen D), Burgert TS. Polycystic ovary syndrome in adolescence: impaired glucose tolerance occurs across the spectrum of BMI. Pediatr Diabetes. 2013;14(1):42-9.

2. Zawadzki JK, Dunaif A. Diagnostic criteria for polycystic ovary syndrome: towards a rational approach. Polycystic ovary syndrome. Boston: Blackwell Scientific; 1992. p.377-84.

3. Balen A. Polycystic ovary syndrome and cancer. Human Reprod Update. 2001;7(6):522-5

4. Diamanti-Kandarakis E, Dunaif A. Insulin resistance and the polycystic ovary syndrome revisited an update on mechanisms and implications. Endocrine Rev. 2012;33(6):981-1030.

5. Franks S, Stark J, Hardy K. Follicle dynamics and anovulation in polycystic ovary syndrome. Human Reprod Update. 2008;14(4):367-78.

6. Morin-Papunen L, Rantala AS, Unkila-Kallio L, Tiitinen A, Hippeläinen M, Perheentupa A, et al. Metformin improves pregnancy and live-birth rates in women with polycystic ovary syndrome (PCOS): a multicenter, double-blind, placebo-controlled randomized trial. | Clin Endocrinol Metab. 2012;97(5):1492-500
7. Chakravorty R, Athwal A, Sur D, et al. A prospective, randomized trial comparing the effects of letrozole versus clomiphene citrate for induction of ovulation and pregnancy rate in women with polycystic ovary syndrome. Fertil Sci Res. 2016,3(2):93-7.

8. Legro RS, Arslanian SA, Ehrmann DA, Hoeger KM, Murad MH, Pasquali $\mathrm{R}$, et al. Diagnosis and treatment of polycystic ovary syndrome: an Endocrine Society clinical practice guideline. J Clin Endocrinol Metab. 2013;98(12):4565-92.

9. Chen MJ, Ho HN. Hepatic manifestations of women with polycystic ovary syndrome. Best Pract Res Clin Obstet Gynaecol. 2016:37:119-28.

10. Mahamed RR, Maganhin CC, Sasso GRS, Jesus Simões M, Baracat MCP, Baracat EC, et al. Metformin improves ovarian follicle dynamics by reducing theca cell proliferation and CYP-17 expression in an androgenized rat model. J Ovarian Res. 2018;11(1):18.

11. Soares Júnior JM, Baracat MC, Maciel GA. Polycystic ovary syndrome: controversies and challenges. Rev Assoc Med Bras (1992). 2015;61(6):485-7. 